\title{
La Odisea homérica y la cueva como arquetipo de paisaje rural y primer hábitat mediterráneo
}

\author{
The homeric Odyssey and the cave as an archetype of rural \\ landscape and first mediterranean habitat
}

\author{
Víctor Díaz López ${ }^{1}$ \\ Fecha de recepción: 22-06-2021 - Fecha de aceptación: 19-07-2021 \\ Hábitat y Sociedad (ISSN 2173-125X), n. ${ }^{\circ}$ 14, noviembre de 2020, pp. 287-302. \\ https://doi.org/10.12795/HabitatySociedad.2021.i14.15
}

\section{Summary}

The search for an answer to the question of when the landscape begins, brings us closer to a subject as complex as that of looking for traces of landscape in Homer's genesic works. From a phenomenological analysis of literary texts, we are forced to draw on such heterogeneous sciences as psychology, painting or geography, to promote a transdisciplinary convergence that helps us in our search for landscape and housing archetypes from attentive and inquisitive readings of the Homeric hexameters and some of the possible objectifications of their places of indeterminacy.

We focus on the Odyssey, Homer's second masterpiece, recited and written at the end of the 8th century $\mathrm{BC}$ and considered the germ of Western literature. Such an epic narrative develops complex plots in settings belonging to known and differentiated territories known as "Hellas". In short, Homeric stories necessarily take place in a "place", be it real, imaginary or fictitious, of a physical space or vital territory- in which action and daily life will take place.

The Poet, as aedo-educator, selects stereotypical natural or cultural spaces of the Mediterranean in order to show archetypes of nature, geography, the polis, and the Mediterranean landscape itself, as an educational and unifying program for the dispersed peoples of Hellas. And the objectifications of that Homeric world, carried out throughout history by different memory repositories, will be the basis for the creation of the West. Here we dare to identify the cave -located on mountainous limestone slopes and facing the sea- with the archetype of the first Mediterranean rural landscape and habitat.

Key words

Landscape; Phenomenology; Homeric; Archetype; Mediterranean

\section{Resumen}

La búsqueda de una respuesta a la pregunta de cuándo comienza el paisaje, nos aproxima a un tema tan complejo como el de buscar sus trazas en las genesíacas obras de Homero. Desde un análisis fenomenológico de textos literarios, nos vemos obligados a recurrir a ciencias tan heterogéneas como la psicología, la pintura o la geografía, para propiciar una convergencia transdisciplinar que nos ayude en nuestra búsqueda de arquetipos paisajísticos y habitacionales desde unas lecturas atentas e inquisitivas de los hexámetros homéricos y algunas de las posibles objetivaciones de sus lugares de indeterminación.

Nos centramos en la Odisea, segunda obra cumbre de Homero, recitada y escrita a finales del siglo viII a. C. y considerada germen de la literatura occidental. Tal narración épica desarrolla complejas tramas en unos escenarios pertenecientes a territorios conocidos y diferenciados que se conocen como "Hélade". En definitiva, los relatos homéricos suceden necesariamente en un "lugar" —ya sea real, imaginario o ficticio-, en un espacio físico o territorio vital en el que se desarrollará la acción y la vida cotidiana.

El Poeta, como aedo-educador, selecciona espacios naturales o culturales estereotípicos del Mediterráneo para conseguir mostrar arquetipos de la naturaleza, la geografía, la polis, y el propio paisaje mediterráneo, como programa educativo y unificador de los dispersos pueblos de la Hélade. Y las objetivaciones de aquel mundo homérico, realizadas a lo largo de la historia por distintos depósitos de memoria, irán fundamentando la creación de Occidente.

Aquí nos atrevemos a identificar a la cueva —situada en laderas calizas montañosas y frente al mar- con el arquetipo de primer paisaje y hábitat rural mediterráneo.

\section{Palabras clave}

Paisaje; Fenomenología; Homérico; Arquetipo; Mediterraneidad

1 Arquitecto. Email: victordiazlopez.arquitecto@gmail.com 


\section{Introducción: ¿Homero como original paisajista de la mediterraneidad?}

El presente texto recoge y adapta uno de los apartados nucleares de una investigación doctoral y más extensa que quiere ser una respuesta propia a una pregunta recurrente: ¿Cuándo comienza el paisaje? Agustín Berque, uno de los más conocidos epistemólogos del paisajismo afirma que "desde un determinado punto de vista descentrado - el de las ciencias de la naturaleza- el paisaje no ha tenido ni que nacer ni que inventarse; siempre ha estado allí (o casi), porque es la forma de determinada porción de superficie terrestre". Si bien continúa afirmando que "desde otro punto de vista — esta vez el centrado en la percepción humana - tiene desde luego una historia" (Berque 2009, p. 81). Así pues, y exclusivamente asociado a la pintura occidental, signifiquemos que, como género específico, la mayoría de autores parece coincidir en que se inició en los Países Bajos. Pero nosotros vamos a situarnos en ese antes no tan solo del establecimiento en nuestra cultura occidental del término "paisaje" o del género "paisajismo" (Rubio Tenor y Ojeda Rivera, 2018), sino de la concepción posterior del propio paisaje, anterior al género. Alain Roger bautiza tales actuaciones realizadas antes de la supuesta fijación del paisaje con el término de "protopaisaje" (Roger 2007, pp. 55-70).

Pero, ¿qué ocurrió entonces? Nos hemos atrevido a adentramos en la obra del poeta griego Homero con el objetivo de buscar unas posibles identificaciones y existencias en ella de "paisajes significativos". Nos centramos en la "Ilíada", datada hacia el 750 a. C., y en la "Odisea", de finales de aquel mismo siglo VIII a. C., obras que pueden considerarse como las primeras de la literatura de Occidente y que son narraciones épicas que desarrollan distintas tramas y personajes en determinados lugares y situaciones dentro de una tradición griega que posiblemente quedase fijada en aquellos siglos y en la que se enmarcan dioses y héroes, perteneciendo a unos territorios diferenciados y conocidos como la "Hélade", de manera que todos aquellos relatos suceden necesariamente en un "lugar", ya sea real, imaginario o ficticio, de aquel espacio vital y físico en el que se desarrollará la acción y la vida cotidiana.

En la primera de las obras, la Ilíada, el Poeta, posiblemente un joven aedo que recoge parte de la tradición de sus antecesores del extenso "Ciclo Troyano", se centra en un periodo muy corto que sucede al final de la guerra entre teucros y aqueos y que se condensa en "la cólera de Aquiles". La ciudad amurallada de Ilión, mirando al mar y separada de este por una gran explanada, es escenario de cruentas luchas, en su borde, en la playa y el campamento se tensiona con la ciudadela en un binomio geográfico y humano entre helenos - los que llegan del mar-y troyanos - que se protegen de los invasores-.

En la Odisea, pensamos que el Homero maduro, más que recopilar, escribe, narra, modela la tradición heredada de los aedos en una bella y emotiva historia, cuyo cordón umbilical se centra en Troya-Ítaca. Cuenta - en un viaje que parece no tener fin- las desdichas y anhelos del héroe Odiseo por regresar a su tierra, a su hogar, a reencontrarse con los suyos. Se jalonan las travesías marítimas y los desembarcos en territorios ignotos, dominados y supervisados por los dioses inmortales, quienes desde el Olimpo dirigen el destino de los hombres y del infeliz protagonista.

No obstante, observamos que estas lecturas quedan limitadas por el desconocimiento de una parte importante de los recursos utiliza- 
dos por el Poeta, propios de la Grecia Arcaica, como son el uso de la mitología, la geografía y el contexto sociopolítico de la época, lo que podríamos denominar el mundo homérico de la "Ilíada" y la "Odisea". Homero, como otros muchos aedos, narra sus historias con un objetivo pedagógico y dentro del contexto espacial claramente definido de la cuenca mediterránea, de manera que sus obras suponen la primera vez que se realiza una aproximación al medio físico natural y humano, la primera vez que se tiene constancia de la recreación de los territorios que conforman lo que hoy reconocemos como nuestro mundo mediterráneo. Etimológicamente, como "mar entre tierras", pueden ser también identificados, por ejemplo, el Caribe o el Mar Negro, pero geográficamente, la mediterraneidad se identifica a escala planetaria por un clima, presente en unos ámbitos situados en los costados occidentales de los continentes y en los sures de las latitudes templadas, caracterizado por una prolongada estación seca estival que viene determinada por las influencias de los anticiclones subtropicales. Cinco son sus ámbitos - sur europeo, californiano, chileno, surafricano y australiano-, pero el más genuino es el que los bautiza, porque rodea al propiamente dicho mar Mediterráneo entre la Europa meridional, el norte de África y el próximo Oriente.

Las claves comprensivas y genuinas de este ámbito geográfico pueden categorizarse desde tres perspectivas: Claves fisico-naturales - mar interior, rodeado de montañas jóvenes (alpinas) y calizas (esponjosas y erosionables) y llanuras anegables, en un ambiente especialmente condicionado por la maresía o el "efecto marino", ríos cortos y espasmódicos (ramblas, inundaciones...), calor y sequía estival-. Claves territoriales o históricas - ecúmene o territorio habitado, en el que se han ido cruzando numerosas culturas en un prodigio de hibridismo, adaptabilidad, conflicto y convivencia y cuna de la ciudad como sustancial nodo territorial, que une redes de comunicación y superficies reconocidas-. Claves culturales o paisajisticas - paisajes rurales semidesérticos y blanquecinos (sequía, caliza y erosión), variopintos e híbridos (rincones, luz, fuentes, regadío), paisajes urbanos fortificados, ajardinados y vivibles, asentados en una vieja y elaborada conciencia de singularidad respecto de los territorios exteriores- (Ojeda Rivera, 2021).

\section{Hipótesis de partida y objetivos pedagógicos de los textos homéricos}

Con aquellas claves o referencias y, tras lecturas sucesivas de la Odisea, se parte aquí de la hipótesis de que las cuevas — situadas en las laderas montañosas y frente al mar-se constituyen en gérmenes arquetípicos del primer paisaje y hábitat rural mediterráneo.

Como la Ilíada pretende ser un manual de aprendizaje y reconocimiento de la identidad territorial y tribal de los pueblos de la Hélade - catálogo de naves, escudo de Aquiles, metáforas y cosmos helénico-, la Odisea tendrá un objetivo específico de manual de enseñanza moral: el valor de la familia y de la pertenencia a un determinado espacio natural, a sus territorios o países, así como a sus paisajes y lugares concretos. Ello explica que en el segundo texto homérico de la vuelta de Ulises se puedan encontrar innumerables descripciones geográficas de espacios naturales, montañas, bosques, costas o ensenadas de este Mediterráneo, mar antiguo, tenebroso y lleno de intrigas, el hogar del todopoderoso e iracundo Poseidón, donde una multitud de criaturas 
fantásticas se confabulan en su venganza y no perdonarán a Odiseo la muerte de uno de sus hijos —el gigante Polifemo- y solo a regañadientes y por orden del dios, Zeus, dominador del Olimpo y padre de dioses y hombres, dejarán que regrese a Ítaca. Pero, amén de las posibles interpretaciones personales de los traductores, los distintos hexámetros de la Odisea están cargados de indudable belleza poética, que, emanada del aedo Homero, es utilizada para afianzar una clara y evidente enseñanza moral en las acciones de sus propios personajes: los valores morales de la familia, la fidelidad de los esposos y el papel del hijo como valedor de tales valores en la ausencia del padre.

\section{Justificación y metodología: Lecturas y objetivaciones de la obra literaria y sus lugares de indeterminación}

Es este un trabajo de indagación pluridisciplinar basado en las consideraciones teóricas del paisaje y en sus expresiones pictóricas, literarias y geográficas, a partir de las cuales se irá procurando una convergencia inter y transdisciplinar mediante la aplicación de un método de lectura hermenéutica. Todo ello se inicia con una aproximación rigurosa e interpretativa de los textos homéricos, que nos permitirá acercarnos a las claves de la construcción de paisajes mediterráneos por el Poeta y a sus respectivas copertenencias, así como a seleccionar unos textos significativos que leeremos hermenéuticamente (Ojeda Rivera, 2013).

Nuestra decisión de buscar paisajes en los textos homéricos quizás surja como reacción a la valoración que hacen determinados teóricos sobre el origen del "concepto de paisaje", no del "género paisajístico" que comúnmente se suele fijar en la pintura flamenca del siglo XVII. Hay autores que sitúan el origen del paisaje en el Neolítico, ${ }^{2}$ aunque también se encuentra quienes opinan que "el mundo griego constituyó indiscutiblemente una de esas culturas no paisajistas" (Maderuelo, 2005, p. 44). No dudamos que el pensamiento griego se fijase principalmente en el hombre como ser, en su interior, objeto básico de la filosofía, pero no compartimos la posición que conduce a la afirmación de que "la antigüedad mediterránea había estado tan profundamente arraigada en el sentido griego de los valores humanos que este concepto de la naturaleza había desempeñado un papel secundario" (Clark, 1949, p. 33). Particularmente, a nosotros nos parece tal visión un poco sesgada y simple, porque en ella se obvian las expresiones artísticas —arquitectónicas, escultóricas o pictóricas- que quieren ser objetos complementarios de nuestra investigación humanista y transdisciplinar.

Metodológicamente, seguimos la propuesta fenomenológica del fi2 "La concepción del lugar. A las puere historias del jardín y del paisaje que presentan las construcciones megalíticas de Stongenge y Avebury como los orígenes del jardín. Por ejemplo: Jellicoe, Geoffrey y Susan (1995). El paisaje del hombre. La configuración del entorno desde la prehistoria hasta nuestros días. Barcelona: Gustavo Gili. También es frecuente encontrar interpretaciones de los árboles y plantas que aparecen en los bajo relieves asirios del siglo VII a. C. que se encuentran en el Museo del Louvre, como esquemáticas representaciones de jardines e, incluso, identificarlas con el Paraíso Terrenal”. Citado por Javier Maderuelo (2005, p. 64). lósofo polaco Roman Ingarden (1893-1970) — discípulo del también filosofo Edmund Husserl (1859-1938), fundador de la corriente fenomenológica en el análisis de la obra literaria-, que ha quedado recogida en dos de sus publicaciones: La obra de arte literaria, 1960 y La comprensión de la obra de arte literaria, 1968. El análisis de un posible paisaje a través de un soporte físico resulta a priori más abordable; pensemos en la pintura o en la geografía, pero ¿qué ocurre en la literatura? Pocos son los teóricos que ahondan en los paisajes literarios, coincidiendo en identificar generalmente los ejemplos más evidentes, pero encontramos una interesante excepción en Claudio Guillén, cuyo Ensayo de literatura comparada nos condujo precisamente a descubrir el método de Ingarden y a profundizar en su obra: "Ya desde Roman Ingarden, el gran fenomenólogo polaco, comprendimos que la obra literaria es 
una estructura esquemática, cuyos huecos, silencios y otras indeterminaciones han de ser suplidos y concretados por la actividad del lector. La fenomenología permite asimismo percibir como la lectura admite una "suspensión voluntaria del descreimiento"” (Guillén, 1998, p. 98).

\section{Lectura pasiva y lecturas activas}

Ingarden distingue la primera lectura, a la que denomina pasiva, de las sucesivas o activas. La primera es la que realizan en general los lectores no especializados. En este caso, la narración se conoce en la medida en que se avanza en el texto, llegándose a la comprehensión del argumento en el desenlace final. Las lecturas sucesivas se realizan para proceder a los análisis específicos detectados en la primera, procediendo a la analogía con textos de la propia época, incluso con la utilización de diferentes traducciones, así como con el apoyo de una bibliografía seleccionada y agrupada a tenor de los conocimientos que aporta, afirmando o negando las premisas iníciales, obteniendo con las conclusiones premisas nuevas que arrojarán luz sobre las primeras intenciones.

Importantes reflexiones, derivadas del objetivo de identificar paisajes, van conduciendo aquellas lecturas activas a la objetivación, una vez seleccionadas aquellas partes de la narración en las que queda formalizada y se convierte en mecanismo de la mayor importancia en la comprensión y aprehensión de la obra de arte literaria, ya que los paisajes literarios son experiencias estéticas en el interior de experiencias literarias, condición singular y doble.

\section{Objetivaciones}

Tanto en la lectura pasiva como en las activas, nuestra imaginación recurre a la facultad psíquica de rescatar de nuestra memoria los recuerdos e imágenes que almacena. Construye escenarios, da vida a personajes, activando una estrecha relación entre el texto creado por otro individuo con el lector, quien construye su propio relato. A estas posibles reconstrucciones, Ingarden las denomina objetivaciones, que se materializan con los distintos depósitos de conocimiento.

Podríamos considerar a Sigmund Freud (1856-1939), fundador de la psicología moderna, como un precursor de este método, cuando vemos cómo recoge - en la introducción de su obra sobre La interpretación de los sueños - gran parte de lo que con anterioridad se había escrito sobre las imágenes utilizadas en la construcción de los sueños: "En mayor o menor grado, el contenido de los sueños queda siempre determinado por la personalidad individual, por la edad, el sexo, la posición, el grado de cultura, y por los sucesos y enseñanzas de su pasado individual" (Freud, 1976 [1889], I, p. 23). Las consideraciones de Freud son análogas a las de Ingarden y nos llevarían a entender que cualquier lector, no ya del ámbito territorial de la Hélade, sino de cualquier ubicación espacial y temporal, realizará su propia objetivación del material narrativo homérico y que nosotros ampliaríamos al oyente, circunstancia especifica de los primeros objetivadores de la obra griega.

\section{Lugares de indeterminación}

Así pues, la objetivación que construye nuestra imaginación se nutre de la propia memoria individual, es un acto subjetivo en el que cada lector produce su propio relato. No obstante, y por otra parte resulta 
obvio, el hecho viene sugerido y mediatizado por la narración, es el autor quien con su propia objetivación construye el armazón de su propio relato, el boceto que cada uno rellenaremos con nuestras propias imágenes: Para un lector de color, Odiseo sería negro; para un haitiano, la cueva de Calipso estaría en el Caribe y para un asiático el palacio de Alcínoo probablemente sería una pagoda.

Es, pues, en los lugares de indeterminación donde el autor puede dar mayor libertad a la construcción subjetiva y, donde, o por contra, podrá utilizar este recurso en pos de determinadas acciones. Resulta proverbial la gran maestría de Homero en el manejo de este recurso en la Odisea, analizando la cueva de la ninfa Calipso. Pensemos que cualquier lector, sea cual sea su procedencia, desde pertenecer al área mediterránea, como los primeros receptores de la obra, o, en la actualidad, a cualquier otro punto del globo, todos realizarán su objetivación subjetiva; si nos referimos a las descripciones homéricas de Ítaca, nos las describirían con aspectos posiblemente muy distintos, pero siempre la situarían con certeza en el Jónico, con unas características geográficas reconocibles, con unos visos de existencia reales. Si la construcción la tuviésemos que realizar sobre la isla de los cíclopes, no tendríamos tan claro el apoyo de una realidad cierta, y cada lector acomodaría la subjetivación a su propia existencia, variando sensiblemente de una a otra. Nos encontraríamos claramente ante un lugar de indeterminación.

De acuerdo, pues, con esta metodología de la objetivación de la obra literaria, las imágenes que nuestra memoria construye de un texto son convicciones estéticas nacidas de la propia experiencia literaria. Así, la narración épica relatada en los hexámetros de la Odisea, se condesa en imágenes únicas que se construyen en nuestra mente, en nuestra imaginación, utilizando el recuerdo de la naturaleza cercana, que acumulamos en nuestra memoria y que para los primeros oyentes-lectores de Homero, sin lugar a duda, era la naturaleza mediterránea. Así, nos encontramos en disposición de afirmar claramente que en muchos textos de Homero los paisajes constituyen un recurso narrativo. $\mathrm{Y}$ en aquella narración, la trama se desarrolla mediante una acción que, sea de la escala que sea, sucede en un "lugar", de manera que el oyente, lector u observador, mediante su imaginación y el depósito de su memoria, participará y construirá su propio relato en su propio "lugar".

$\mathrm{Si}$ en las artes plásticas, y pese a que podamos interiorizar el contenido, el observador se sitúa fuera (delante del cuadro), en los ojos del creador o detrás de él, en la narración literaria se produce una situación similar en la que el lector-oyente se puede situar fuera de la acción, identificado con alguno de sus personajes o ajeno a ellos. No obstante, puede existir también una nueva posición, la que resultaría de situarse dentro del lugar que es narrado o contemplado en la distancia e igualmente identificarse como un personaje o actor o como un observador.

\section{La cueva como arquetipo de paisaje y hábitat rural mediterráneo en la Odisea}

En la Odisea, Homero enfrenta al sufrido Odiseo a cuatro bellas y jóvenes mujeres: la ninfa Calipso, Nausícaa, hija de Alcínoo rey de los feacios, la maga Circe; y, a su esposa Penélope. Las tres primeras, suponen sendas tentaciones en su deambular por el Mediterráneo, desean fervientemente al héroe para sí, y lo tentarán prometiéndole felicidad, ri- 
queza e inmortalidad. Él las rechazará para así poder continuar el camino de regreso a su hogar, demostrando una fidelidad sin parangón a su esposa, Penélope, cuyo propio nombre deriva de la voz pênélops, que significa "ánaectorde", y en el folclore de varios pueblos, las hembras del ánade son consideradas símbolo de fidelidad conyugal, pues se asegura que permanecen unidas de por vida a sus respectivos y únicos compañeros.

Refiriéndose a la personalidad de Ulises, el Poeta añade a los numerosos epítetos de la Ilíada - el muy fértil en recursos, el de muchas astucias, el de ardides numerosos, el destructor de ciudades- una serie de apelativos que no solo lo dibujan como un guerrero astuto, sino que le otorgan unos nuevos atributos que lo convertirán, además, en un héroe sufridor y fiel, en quien los valores morales de la relación entre esposos y la fidelidad ante la ausencia están por encima de todo.

Analizamos, al fin, el que consideramos el "primer recurso de paisaje homérico", que titulamos La cueva de Calipso o el lugar de encuentro de Odiseo con la primera de aquellas bellas mujeres, la nereida hija de Titán, que lo quiere para sí. La descripción que Homero introduce en el desenlace de esta relación ejemplarizará el mensaje moral y educador característico de su obra. Ogigia y Calipso representan la belleza, el paraíso - preludio del locus amoenus - , la felicidad y la inmortalidad. La bella ninfa le ofrece a nuestro héroe inmortalidad, uno de los deseos más buscados por el hombre, anhelo que ha acompañado la desdichada existencia de todos aquellos que han querido alcanzarla, como claramente expresa la diosa enamorada de nuestro héroe. Pero, parece no ser suficiente. El terco Odiseo desea, como cualquier mortal, volver a su patria, pisar el suelo itacense y reunirse con su familia, con su bella esposa Penélope y su hijo, al que dejó recién nacido al partir hacia Troya. Calipso no llega a comprender por qué nuestro héroe desea regresar y no encuentra en ella lo que tantos otros desearían. Se lamenta y pregunta:

\title{
(V 209-13, Gr):
}

... por mucho que estés deseando

ver de nuevo a la esposa en que piensas un día tras otro.

Comparada con ella, de cierto inferior no me hallo

ni en presencia ni en cuerpo, que nunca mujeres

mortales en belleza y en talla igualarse han podido a las

diosas.

$$
\text { (V 219-20, Gr) }
$$

Mas con todo yo quiero, y es ansia de todos mis días, el llegar a mi casa y gozar de la luz del regreso.

\author{
(XXIII 333-6, Gr) \\ ... la diosa Calipso \\ procuró retenerle en su cóncava gruta intentando \\ que con ella casase; sustento le dio y aun \\ promesa \\ de volverle inmortal, de la vejez liberado por siempre...
}

Ante la insistencia de Atenea, Zeus accede a liberar a Odiseo retenido por Calipso y envía a Hermes para que traslade a la ninfa su decisión (V 7-35, Gr).Tuvimos que releer detenidamente estos pocos hexámetros del canto quinto de la Odisea, porque ya en una primera lectura, 
sentimos cierta emoción, como un descubrimiento, con la sensación de que podríamos encontrarnos ante El caminante sobre el mar de nubes, uno de los cuadros más admirados del paisajista romántico alemán Caspar David Friedrich. Aquella interrogación de si sería Hermes el Wonderer que retrató Friedrich y esa primera impresión, producto de la artealización de la escena, fueron las bases para seleccionar este pasaje como típicamente paisajístico. No obstante, una vez profundizado el análisis, tras varias lecturas reflexivas, llegamos a la conclusión de que la contemplación de Hermes poco tiene que ver con la del romántico. No quiere esto decir que no hayamos objetivado una imagen de un paisaje, pero debemos entender que este mensaje transmite otra enseñanza, como veremos seguidamente.

De las tres traducciones que hemos utilizado para extraer estos bellos hexámetros (Odisea, V 63-75), la de José María Pabón para Gredos, la de José Luis Calvo en la edición de Cátedra y la de Luis Segalá y Estalella en Austral, cada cual aporta los matices propios de las interpretaciones de los traductores - como diría Borges (1932, p. 68), cada traductor se convierte en autor- No obstante, las tres expresan el mismo contenido:

A la cueva servía de cercado un frondoso boscaje de fragantes cipreses, alisos y chopos, en donde tenían puesto su nido unas aves de rápidas alas, alcotanes y búhos, chillonas cornejas marinas de la raza que vive del mar trajinando en las olas. En el mismo recinto y en torno a la cóncava gruta extendíase una viña lozana florida de gajos.

Cuatro fuentes en fila, cercanas las cuatro en sus brotes, despedían a lados distintos la luz de sus chorros; delicado jardín de violetas y apios brotaba en su torno: hasta un dios que se hubiese acercado a aquel sitio quedaríase suspenso a su vista gozando en su pecho. Así en pie contemplándolo estuvo el heraldo Argifonte y...”. (Gr)

En torno a la cueva había nacido un florido bosque de alisos, de chopos negros y olorosos cipreses, donde anidaban las aves de largas alas, búhos y halcones y las cornejas marinas de afilada lengua que se ocupan de las cosas del mar. Había cabe a la cóncava cueva una viña tupida que abundaba en uvas, y cuatro fuentes de agua clara que corrían cercanas unas de otras, cada una hacia un lado, y alrededor, suaves y frescos prados de violetas y apios. Incluso un inmortal que allí llegara se admiraría y alegraría en su corazón. El mensajero Argifonte se detuvo allí a contemplarlo...". (Ca)

Rodeando la gruta, había crecido una verde selva de chopos, álamos y cipreses olorosos, donde anidaban aves de luengas alas; búhos, gavilanes y cornejas marinas, que se ocupan de cosas del mar. Allí mismo, junto a la honda cueva, extendíase una viña floreciente, cargada de uvas, y cuatro fuentes manaban, muy cerca una de la otra, dejando correr en varias direcciones sus aguas cristalinas. Veíanse en contorno verdes y amenos prados 
de violetas y apio; y, al llegar allí, hasta un inmortal se hubiese admirado, sintiendo que se le alegraba el corazón. Detúvose el Argifontes a contemplar aquello, y... (au)

Zeus, padre de dioses y hombres, ha ordenado a su hijo "Hermes, puesto que tú eres mensajero, ${ }^{3}$ en lo demás" (V, 29), que vaya a la isla de Ogigia y ordene a la Ninfa que deje marchar a Odiseo. El Mensajero, dios de las fronteras y los viajeros y transmisor de los mensajes de los dioses a los hombres, como hermeneús o "interprete", es enviado por Zeus para que llegue, mire, contemple, observe y transmita el mensaje, y, con ello, Homero nos hace copartícipe, nos empuja e implica en la acción, necesita que participemos del mensaje. Después de describir la cueva y sus alrededores como un "locus amoenus" de gran belleza - frondoso boscaje, fragantes cipreses, aves de rápidas alas, viña lozana florida de gajos, fuentes despedían luz de sus chorros-, nos indica cómo antes de proceder el mensajero se queda a "contemplar".

Hermes es observador desde la distancia y el oyente-lector se sitúa imaginariamente un paso atrás, observando incluso al que observa. Se está produciendo una objetivación: La narración indeterminada de lo que unos quisieron concretar en un lugar se convierte en una ficción común, de manera que, al escuchar o leer aquellos hexámetros, podríamos pensar que todos conocemos un lugar con esas características: alguna vez disfrutamos de las sombras de un frondoso bosque. ¿Quién no escuchó, paseando entre acantilados, el graznar de las aves o recogió racimos de uvas en aquellas cepas regadas por el agua corriente de las fuentes? "Igual que la vida, la Literatura y la Geografía —en sus más amplias acepciones- son el cruce de cientos, de miles de hilos que van urdiendo las observaciones y las vivencias con el azar y la pericia de unos tejedores hasta lograr que broten, en palabras de Henry James, la figura en el tapiz: obra literaria o descripción geográfica" (Ojeda Rivera y Villa, 2016, p. 14).

Las tres traducciones manejadas concluyen de igual modo, el "Argifontes contempla”, acción directamente relacionada con el paisaje y que podríamos sintetizar como la "artealización del espacio geográfico", entendiendo artealizar como que "el paisaje no solo debe ser observado, descrito y explicado; sino también debe ser mirado, captado y comprendido" (Ortega Cantero, 1987, p. 118). Profundizando en su contenido y consultando la etimología de la palabra ${ }^{4}$ contemplar, deriva del latín contemplare, que está formado sobre templum (derivado de tem/tom- "cortar", visible aún en tomo "sección de un tratado en un solo volumen" y en medicina -(ek)tomía "extirpación"). Este sustantivo designa en origen "el espacio delimitado por el augur en el cielo, y sobre la tierra, en el interior del cual este recoge e interpreta los presagios", según explica Varrón (Lingua Latina 7, 6) y recoge oportunamente el Dictionnaire étymologique de la langue latine. Historie de mots de Ernout-Meillet s.v. templum, del vocabulario de los augures y que de ahí pasó a la lengua general con el significado que ahora tiene: "examinar (especialmente con la mirada atenta)". Una etimología parecida tiene nuestro verbo considerar (derivado de sidus, "constelación celeste"), con lo que el verbo sería también un tecnicismo propio del vocabulario de los augures y significaría algo así como "examinar la combinación de las estrellas que permiten adivinar el futuro de una persona". En ambos casos, el uso específico de las lenguas de la adivinación habría pasado a un uso puramente laico, que es el habitual en latín. ¿Implicarían estos verbos
3 Homero. (1982). "En la Ilíada, unos años antes, Homero había recalcado en varias ocasiones la calidad de Hermes como heraldo" en Ilíada. Edición y traducción Crespo Güemes, Emilio. II 103, p. 24. XXI 497, p. 431. XXIV, 178, 282, $339,352,378,410,432,445,678$, pp. 487 , 490,492 a 496.

4 Consultas realizadas en 2019 a Emilio Crespo Güemes, profesor en Filología Griega en la UAM y a Rocío Romero Domínguez, catedrática de Filología Griega y Licenciada en Filología clásica, española e inglesa. 
griegos la existencia de una concepción cultural subyacente de acuerdo con la cual la naturaleza induce al ser humano a examinarla como espectáculo o como fuente de admiración? ¿Podría intuirse por su relación con el disfrute teatral (poesía, música, danza) una relación emocional y espacial entre el sujeto-espectador y la obra o espectáculo contemplado?

Un singular precedente entre la acepción "contemplar" en griego antiguo y la raíz de "teatro" la podemos encontrar en los estudios renacentistas de la perspectiva en Italia. Mantegna trataba de demostrar, al igual que muchos otros pintores coetáneos, que la pintura era una "ciencia" derivada de los principios rigurosos de la geometría euclidiana, pues se fundamentaba en las reglas de la perspectiva lineal. Cómo el descubrimiento de esa malla geométrica ideal regulando toda la representación pictórica era de tal importancia que condicionó indefectiblemente, también, la concepción renacentista del paisaje natural. Y cómo todo esto enlazaba la pintura renacentista y el escenario teatral, donde el rectángulo del cuadro se trasladaba a la cara frontal del espacio cúbico de la escena. Un ejemplo de esta simbiosis lo constituyen los decorados teatrales publicados por Serlio (Ramírez, 1993, pp. 192, 195, 197). La escena griega abierta o delimitada inmaterialmente del fondo de escena y los laterales de sus teatros nos lleva, citando a Nicolás Ortega Cantero (1987), a: "contemplar, es observar, pensar, sentir e imaginar".

Recuperando el discurso en su inicio, cuando citábamos a las cuatro bellas mujeres de la Odisea, observamos que la ninfa Calipso es la primera que desea para sí al Laertìada, pero su esposa es Penélope. Homero da a Atenea, la iniciativa, impulsora de la acción, que materializará con la contemplación de Hermes. Podríamos asegurar que el Poeta nos presenta una escena de un paisaje idílico en su concepción que, en su comprensión dentro de la totalidad de la obra, aporta un valor pedagógico y moral. Este bello paisaje, claramente mediterráneo, de una cueva o cavidad en una ladera rocosa de caliza, podría encontrarse en cualquier punto de nuestras costas, en las islas del Egeo, en las costas de Anatolia, en el Peloponeso, en Eubea, Sicilia, incluso, en las costas africanas. Podemos afirmar, pues, que Homero crea y utiliza estas descripciones a modo de "arquetipo" de paisaje rural primario, que contempla y se defiende del mar y de los peligros del llano y previo a las complicadas conquistas de las campiñas abiertas y pantanosas.

En la literatura, la mirada del subconsciente es vagabunda, se desliza y se detiene en lo más inesperado de nuestra memoria. Cuando leemos nos transmutamos de un personaje a otro: tan pronto miras al que miras que eres el que miras, asumiendo sus sentimientos y situación particular. Al escuchar o leer los hexámetros de la Odisea que comentamos, todos miramos, contemplamos con los ojos de Hermes y en él nos transformamos y, al percibir el paisaje en el interior, lo acercamos a nuestros lugares, si soy ático a Ática, si de Beocia, allí, etc. El gran acierto está en que todos puedan interactuar en la obra literaria (lector y personajes): Cada espectador u oyente, ante las historias narradas, recupera sus propios recuerdos, los que acumula en su memoria, lugares y sentimientos, o más vitales, como colores, olores, temperaturas, etc.

Como apunta López Silvestre, "el Paisaje es una relación en la que el ojo que capta el entorno que lo rodea sintoniza con él gracias a su previa sintonización interna. Nietzsche sostenía, siguiendo a Stendhal, que cada uno escoge los paisajes que se parecen más al propio modo de ser, de estar o de buscar la felicidad” (López Silvestre, 2013, p. 125) 
$¿$ Construye Homero la cueva de Calipso como un lugar reconocible o identificable? El poeta procede a esbozar con unas precisas y bellas pinceladas un "lugar común" que pudiese ser apropiado por los distintos oyentes-lectores, que pudiese ser fácilmente acercado a los "lugares propios" de cada heleno, perteneciese a la comunidad que perteneciese. Homero, como indudable viajero, ya habría percibido el “"yi” o espiritu del paisaje" (Berque, 2009, p. 83) de muchos de esos lugares determinados de la Hélade, los de aquellos pueblos dispersos, pero unidos por un modo de vida y en sociedades homogéneas a través de sus mitos: todos conocerían a Odiseo, a Calipso o a Nausícaa.

\section{Conclusiones: Del arquetipo a sus posibles y distintas objetivaciones y copertenencias}

Ese esbozo, ese esqueleto, que nos llega a modo de "arquetipo" (Delgado Bujalance y Ojeda Rivera, 2009, p. 122), puede ser completado, vestido y coloreado por cada uno de nosotros, con nuestros propios recuerdos, con aquellos que residen en nuestro depósito de memoria, en definitiva, favoreciendo la apropiación o "copertenencia" (Berdoulay, 2002). Esta última reflexión nos trae a la mente aquellas bellísimas palabras de Besse (2010) de que "en el color se encuentra lo que la geometría no alcanza, la carne del mundo, el lugar mismo de la manifestación de su esencia" (p. 102), sería como si cada oyente-lector rematase su cuadro con su propia paleta de colores, su propia objetivación.

Es en los lugares de indeterminación donde se puede dar mayor libertad a la construcción subjetiva y donde, o por contra, se podrá utilizar este recurso en pos de determinadas acciones. Comprobamos la gran maestría de Homero en el manejo de este recurso en la Odisea, tanto en el episodio de la cueva de la ninfa Calipso como en el palacio del rey feacio Alcínoo. Pensemos que todo lector, sea cual sea su procedencia, desde pertenecer al área mediterránea, como los primeros receptores de la obra o, en la actualidad, a cualquier otro punto del globo, realizará su objetivación subjetiva; si nos refiriésemos a las descripciones homéricas de Ítaca, nos las describirían con aspectos posiblemente muy distintos, pero siempre la situarían con certeza en el Jónico, con unas características geográficas reconocibles, con unos visos de existencia reales, cada lector acomodaría la subjetivación a su propia existencia, variando sensiblemente de una a otra. Nos encontraríamos claramente un lugar de indeterminación.

Identificada la maestría de Homero en la construcción de arquetipos como recurso literario y la objetivación de los mismos como acercamiento a los paisajes homéricos, traemos tres ejemplos de los muchos que se podrían formular: Los dos primeros corresponden a la pintura y el tercero a la apropiación territorial. Recordemos que a lo largo de la historia este atractivo lugar ha sido reclamado para sí, desde aquel pequeño islote en el estrecho de Gibraltar al que nos referiremos o a otro muy pequeño, Gaudo al sur de Creta, o en la isla de Meleda en Croacia, o la cueva de la isla de Gozo en Malta, entre muchos otros.

Muestra de este ejercicio de objetivación arquetípica en la pintura, son las obras que tradicionalmente se han fijado en la literatura antigua de Grecia y Roma; mucha y variada producción que encontramos en un amplio periodo que se desarrollaría hasta el Romanticismo. Nos referimos al conocido género de pintura histórica, la que enlaza con la literatura, o, lo que es lo mismo, convierte la narración en objetivación, 

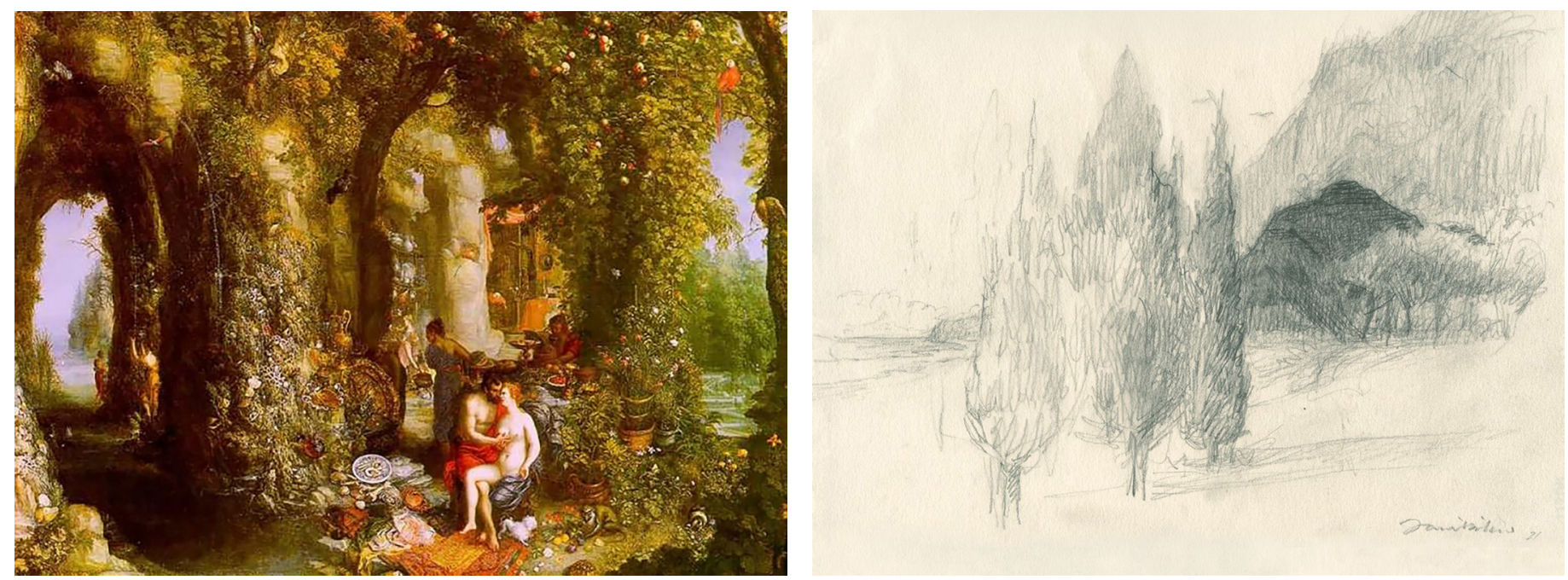

Figura 1 [izquierda]: Banquete de Odiseo con Calipso. Brueghel el Viejo.

Figura 2 [derecha]: Dibujo de Daniel Bilbao.

5 "La pintura de Historia —o sea, de historias mitológicas, bíblicas y literarias-, que ocupa un lugar predominante como "género" pictórico hasta buena parte del siglo XIX [...], dependía, para ser entendida y apreciada, de una ficción mediadora que estaba fuera del cuadro, como una narración conocida, o una leyenda, o un arte diferente, existentes todos en el pasado" (Guillén, 1998, p. 112). hecho siempre subjetivo, donde es el pintor quien interpreta, crea y construye desde su memoria. ${ }^{5}$ Brueghel el Viejo en 1616 lleva al lienzo la cueva en el "Banquete de Odiseo con Calipso" (Figura 1); dominado por el realismo, la exuberancia y luminosidad, es este un cuadro que podemos contemplar en la galería Johnny van Haeften en Londres. La segunda objetivación es la reciente colaboración que ha realizado para nosotros el pintor sevillano Daniel Bilbao en un bello y expresivo dibujo de grafito sobre papel (Figura 2).

Con respecto a la apropiación territorial, me permito contar una experiencia personal: En el año 2019, por cuestiones profesionales he tenido que desplazarme a menudo a la ciudad autónoma de Ceuta, lo que me ha permitido conocerla en profundidad y compartir momentos con algunos de sus locales.

Los griegos situaban el confín oeste de la ecúmene en las columnas de Heracles, estrecho que comunicaría el Mediterráneo con el Océano circular. Flanqueando esta boca se sitúa al norte (al sur de Iberia) el peñón de Gibraltar y al sur, en las costas al norte del continente de Lybia (África), el monte Musa. Al pie de La mujer muerta, como conocemos los hispanos al monte Musa, se encuentra la pequeña península ceutí, que se adentra en el mediterráneo mar de Alborán. Conociendo aquella vieja historia que sitúa en las costas africanas la cueva de Ogigia, tuve la ocasión de preguntar a algunos ceutíes sobre Calipso. Todos aseguran con rotundidad y convencimiento que sí, que Calipso vivió allí. Unos dicen que, en la propia península, mientras otros ubican su cueva en el islote de Perejil. En la escultura que la ciudad le dedicó a la ninfa, reza en una placa que "Pierre Grimal, profesor emérito de la Universidad de la Sorbona de Paris, en su diccionario de Mitología Griega y Romana, afirma que "Calipso vivía en la isla de Ogigia que los autores sitúan en el Mediterráneo occidental y es sin duda en la península de Ceuta, frente a Gibraltar" (p. 83). Apolodoro de Atenas, discípulo de Estrabón, afirma, en su Biblioteca Mitológica, que "Ulises llega náufrago a las costas de Ceuta". La memoria colectiva de "los caballas" (gentilicio ceutí) tiene por muy cierto que Calipso vivió en sus tierras (Figuras 3 y 4).

Un caluroso día de julio, después de la visita a una de mis obras, Mario, el jefe de obras, tuvo la gentileza de acompañarnos a sus costas. Héctor nos acercó desde Cádiz con su velero Camamelo III. Pese a su buen aparejo, foque, mayor y mesana, tuvimos que apoyarnos con el motor. También nos acompañó Manolo, que nos fue de gran ayuda 

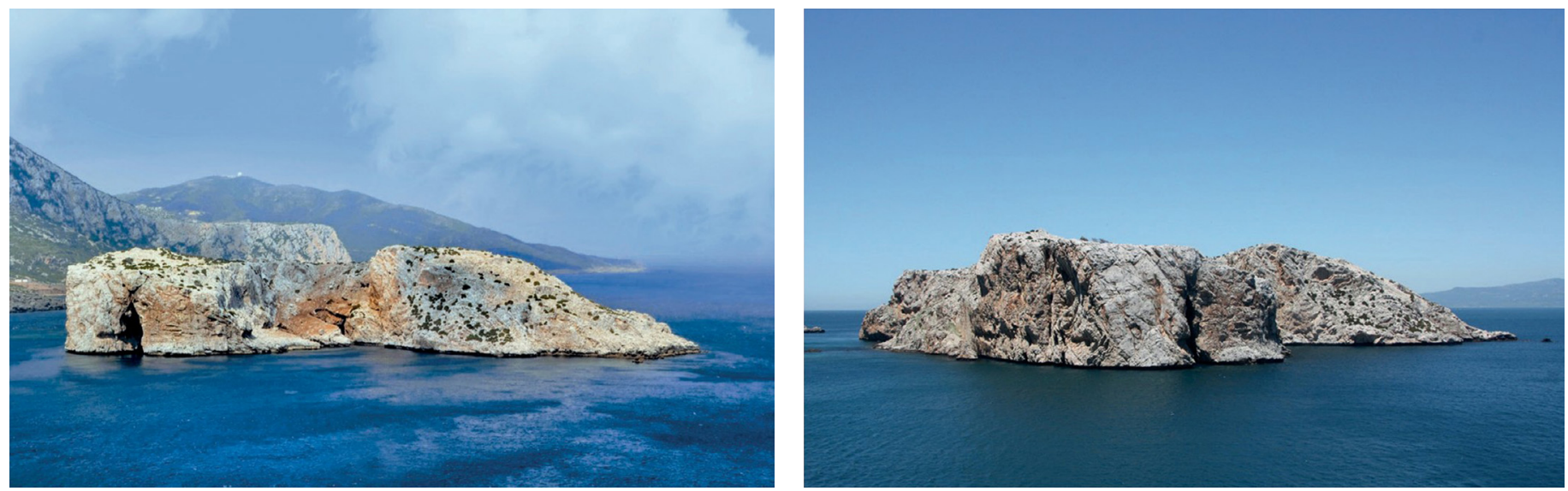

en la gobernación de la nave. Desde el puerto, y costeando en dirección oeste, a algo más de cinco millas náuticas, nos acercamos al pelado islote de Perejil, que rodeamos en sentido horario. Divisamos una escasa vegetación, matorral disperso, pero no advertimos los rastros de cueva alguna. En un acantilado del islote, en el lateral que mira hacia la Ciudad, al este, se puede apreciar una "hendidura". Mario nos contó que él no ha entrado, pero que le han dicho que tiene poca profundidad. Los "caballas" dicen que esa es la cueva, aseveración apoyada por los cronistas locales. Hoy día dicen "que es refugio de alijos de narcotraficantes".

Mirando las verticales paredes de piedra, cómo se mece el mar en su interior y la ausencia total de un trozo de tierra firme donde permanecer en pie, me cuesta pensar que en un pasado remoto hubiese allí cipreses, alisos y chopos, donde hiciesen sus nidos alcotanes, búhos o cornejas marinas. Menos aún una viña y un jardín con violetas y apios. Sorprende la capacidad de apropiación de los lugares indeterminados. Y este debió de ser uno más. Aunque siempre estará en el aire la pregunta: ¿estuvo Ogigia en las costas de Lybia?

Homero continúa con la Odisea la labor educadora ya iniciada en la Ilíada, ensalzando nuevos valores de la convivencia, como es este el caso. Igualmente sostenemos que este paisaje, como evidente "lugar de indeterminación", se convierte en un "lugar de todos", favoreciendo la comprensión y unidad de la Hélade. Pero, no solo será el espacio natural el único elemento de los que dispondrá el oyente-lector, ya que a la configuración material y espacial de la cueva, a esa visión que tenemos a través de los ojos de Hermes, se une "la acción", el sufrimiento de Odiseo, sus ansias por regresar a Ítaca, la necesidad del reencuentro con su esposa e hijo. Recuperando la "Teoría de los valores" de Ingarden: "El elemento que distingue unos valores de otros y diferencia los valores de una especie fundamental de los valores de otra especie fundamental no es otro que la determinación cualitativa de los valores singulares o de las especies enteras de valores. Los valores tendrían, pues, que clasificarse en especies fundamentales y especies subordinadas con arreglo a esa determinación cualitativa” (Ingarden, 1969, p. 13).

Observamos que esta escena que construye el Poeta se basa en dos valores que se complementan, uno estético y otro moral. La belleza del paisaje es, un claro valor cultural de la estética, que se subordina a la fidelidad, el valor moral por antonomasia en la Odisea. El héroe sufre, no es el auditorio, o el espectador, o el lector, estos perciben desde la lejanía unos valores que son ajenos a las intenciones de Odiseo. Parece como si Ingarden hubiese escrito este pasaje después de leer el texto
Figura 3 [izquierda]: Perejil, vista septentrional. Fuente: Mario Valverde Valera.

Figura 4 [derecha]: Perejil, vista meridional. Fuente: Mario Valverde Valera. 
que hemos seleccionado: "Los actos de un hombre que está privado de libertad (de decisión) pueden ser provechosos, pues reportan bien a otros hombres, o, por el contrario, pueden perjudicarles esencialmente; pero, en ambos casos, son, desde el punto de vista de la moral, neutros. Otra condición asimismo solo indispensable del valor moral de los actos humanos es la salud psíquica del agente, que le permite ser responsable de sus actos" (Ingarden, 1969, p. 16). Miramos, miraban, escuchaban, oían, imaginaban, la cueva de Calipso. Homero esboza la idea matriz, la obra de arte con su valor es solo una estructura individual que no se multiplica por los diversos modos de entender de sus contempladores. Cada uno de ellos absorbe la narración y la exporta a su propio territorio, para así construir, para así objetivar con su memoria el paisaje que esboza el Poeta: "El llamado 'agrado', o las 'vivencias de placer', o el 'juicio' no son sino pasajeros conocimientos subjetivos de un hombre que está en contacto inmediato con una obra de arte (o con cualquier otro objeto valioso) [...]. Y, cuando hay muchos contempladores, hay igualmente muchos estados de agrado, sentimientos de placer o juicios, mientras que, en cambio, la obra de arte con su valor es solo una estructura individual que no se multiplica por esos diversos modos de comportamiento de los contempladores" (Ingarden, 1969, p. 21).

Podríamos afirmar, en relación a la existencia del valor de cosas, acontecimientos o procesos, que los valores morales serían "atemporales”, y, así, confirmar que Odiseo y Penélope representan en ese sentido el paradigma de la fidelidad, ejemplo vivo hasta nuestros días. "Es natural conjeturar que el modo de ser del valor se vincula de algún modo con sus diversos elementos: tanto con la materia como con su tipo de valía, como, en fin, con el modo de ser de los objetos en que aparece" (Ingarden, 1969, p. 51). En este caso, en el paisaje homérico, en el que confluyen valores estéticos con valores morales, prevalece la perdurabilidad de los segundos frente a la inmediatez de los primeros.

Desde el punto de vista geográfico, la descripción de la cueva tiene la virtualidad de responder al escenario más reconocido de la mediterraneidad (ámbito conformado por un mar cerrado entre montañas calizas y por un clima semidesértico en el que la vida suele florecer en rincones húmedos y guarecidos de la intemperie). Las cuevas calizas frente al mar y a salvo de los vientos dominantes ofrecen el escenario y el hábitat genuinamente mediterráneos, en el que se mezclan aguas retenidas en la caliza que surgen por las benditas fuentes-con árboles autóctonos y adaptados, con cultivos típicos —viñas, olivares y cereales- y con conciencia de la "belleza escondida" y encontrada en estos rincones de un ámbito bastante estéril (Ojeda Rivera, 2021). 


\section{Referencias Bibliográficas}

Berdoulay, Vicent (2002). Sujeto y acción en la geografía cultural: el cambio sin concluir. Boletín de la Asociación de Geógrafos Españoles, 34, 51-61. Recuperado el 3 de junio de 2021 de: https:/ / www.bage. age-geografia.es/ojs/index.php/bage/article/ view/427.

Berque, Augustín (2009). El pensamiento paisajero. Madrid: Biblioteca Nueva.

Besse, Jean-Marc (2010). La sombra de las cosas. Sobre paisaje y geografía. Madrid: Biblioteca Nueva.

Borges, Jorge Luis (1996). Obras Completas, Tomos I y II. Barcelona: Emecé Editores RBA Coleccionables. DISCUSIÓN (1932) Las versiones Homéricas.

Clark, Kenneth (1949). El arte del paisaje. Barcelona: Seix Barral. Biblioteca Breve.

Delgado Bujalance, Buenaventura y Ojeda Rivera, Juan Francisco (2009). La comprensión de los paisajes agrarios españoles. Aproximación a través de sus representaciones. Boletín de la Asociación de Geógrafos Españoles, 51, 93-126. Recuperado el 3 de junio de 2021 de: https:/ / www.bage.age-geografia. es/ojs/index.php/bage/article/view/1134.

Freud, Sigmund (19767 [1899]). La interpretación de los sueños. Barcelona: Alianza Editorial. Guillén, Claudio (1998). Múltiples moradas. Ensayo de Literatura Comparada. Barcelona: Tusquets.

Homero (1982 [c. 725 y 700 a. C.]). Ilíada. Introducción, traducción y notas de Emilio Crespo. Revisión de Carlos García Gual. Madrid: Gredos.

Homero (195143 [c. 750 a. C.]). Odisea. Traducción de Luis Segalá y Estalella. Edición de Antonio López Eire. Guía de lectura de Alfonso Cuatrecasas Targa. Barcelona: Austral.

Homero (1998 [c. 750 a. C.]). Odisea. Edición y traducción de José Luis Calvo. Madrid: Cátedra.

Homero (2010 [c. 750 a. C.]). Odisea. Prólogo, Carlos García Gual; traducción José Manuel Pabón. Madrid: Gredos.

Ingarden, Roman (1960). La obra de arte literaria. Barcelona: Taurus.

Ingarden, Roman (1968). La comprehensión de la obra de arte literaria. Ciudad de México: Alter texto.
Ingarden, Roman (1969). Lo que no sabemos de los valores. Madrid: Ediciones Encuentro.

López Silvestre, Federico (2013). Los pájaros y el fantasma. Una historia del artista en el paisaje. Salamanca: Universidad de Salamanca.

Maderuelo, Javier (2005). El paisaje. Génesis de un concepto. Madrid: Abada editores.

Ojeda Rivera, Juan Francisco (2013). Lectura transdisciplinar de paisajes cotidianos, hacia una valoración patrimonial. Método de aproximación. Revista INVI, 78(28), 27-75. Recuperado el 3 de junio de 2021 de: https://revistainvi.uchile.cl/index.php/ INVI/article/view/62563/66468.

Ojeda Rivera, Juan Francisco (2021). La mediterraneidad y algunas de sus expresiones geográficas. IESMALÁ. Instituto de Estudios Sociales del Mediterráneo, África y América Latina. Recuperado el 3 de junio de 2021 de: https:/ / www. iesmala.org/uploads/1/2/4/8/124835554/ la_mediterraneidad_y_algunas_de_sus_expresiones_geogr\% C3\%81ficas.pdf.

Ojeda Rivera, Juan Francisco y Villa, Juan (2016). Urdir paisajes. De los análisis disciplinares a la producción compartida de emociones. En Valero, Eva y Olcina, Juan (Eds.), Geografía y paisaje en la literatura hispanoamericana y española (pp. 185-209). Alicante: Publicaciones de la Universidad de Alicante.

Ortega Cantero, Nicolás (1987). Geografía y cultura. Madrid: Alianza Universidad.

Ramírez, José Antonio (1993). La arquitectura como paisaje. El espacio perspectívico y la posición del espectador. En Fundación amigos del Prado (Ed.), Los paisajes del Prado (pp. 191-206). Madrid: Editorial Nerea.

Roger, Alain (2007). Breve tratado del paisaje. Madrid: Biblioteca Nueva.

Rubio-Tenor, Marta y Ojeda-Rivera, Juan Francisco (2018). Paisaje y paisajismo: realidad compleja y diálogos discursivos. Boletín de la Asociación de Geógrafos Españoles, 78, 245-269. DOI: https://doi. org/10.21138/bage.2436. 
Díaz López, Victor (2021). La Odisea homérica y la cueva como arquetipo de paisaje rural y primer hábitat mediterráneo. Hábitat y Sociedad, 14, 287-302.

<https://doi.org/10.12795/HabitatySociedad.2021.i14.15>

$\bigcirc$ 